\title{
TPM3 Gene Product
}

National Cancer Institute

\section{Source}

National Cancer Institute. TPM3 Gene Product. NCI Thesaurus. Code C129381.

A protein encoded by the TPM3 gene. 